[Regular Paper]

\title{
Promotion of Catalytic Activity and Suppression of Deactivation by Solvent Addition in the Hydrotreating of Atmospheric Residue
}

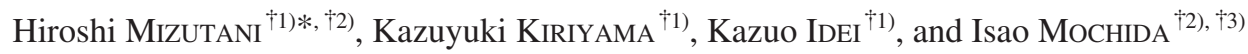 \\ †1) Research \& Development Center, Cosmo Oil Co., Ltd., 1134-2 Gongendo, Satte, Saitama 340-0193, JAPAN \\ ${ }^{\dagger 2}$ Interdisciplinary Graduate School of Engineering Sciences, Kyushu University, 6-1 Kasuga-koen, Kasuga, Fukuoka 816-8580, JAPAN \\ ${ }^{\dagger 3}$ Institute for Materials Chemistry and Engineering, Kyushu University, 6-1 Kasuga-koen, Kasuga, Fukuoka 816-8580, JAPAN
}

(Received September 1, 2003)

\begin{abstract}
The effect of addition of several solvents on atmospheric residue (AR) hydrotreating was examined in the autoclave test. Higher hydrodesulfurization (HDS) activity was obtained by adding solvents in the order of $\mathrm{H}_{2} \mathrm{O}>$ light cycle oil $(\mathrm{LCO})>$ tetralin $>$ none (base) $>1-\mathrm{MN}>$ phenol, using the same volume of solvent. The amount of deposited coke on the catalyst was reduced with all solvents. Larger amounts of tetralin enhanced HDS activity, but tetralin was still inferior to water for the enhancement of HDS in the same molar amounts. The specific effects of $\mathrm{H}_{2} \mathrm{O}$ were confirmed through the activity test. The amount of deposited coke on catalyst with tetralin was similar to that of $\mathrm{H}_{2} \mathrm{O}$. Enhancement of asphaltene desorption reduces coke formation on the catalyst whereas the hydrogenative conversion of solvents with sulfur species in AR may indicate competitive occupation on the active sites. Solvents were not only hydrogenated but also contributed to inhibition of HDS when remaining for long periods on the active sites. Consequently, the inhibition effects of the solvents were considered based on the conversion and evaluation results. $\mathrm{H}_{2} \mathrm{O}$ enhances the desorption of asphaltene and desulfurized products from the catalyst compared with the other solvents. The remarkable effects of $\mathrm{H}_{2} \mathrm{O}$ addition are due to remaining on the active sites for short periods, without inhibiting the HDS activity.
\end{abstract}

\section{Keywords}

Atmospheric residue, Hydrotreating, Water addition, Hydrodesulfurization, Solvent, Coke deposition

\section{1. 緒言}

重質油を精製するプロセスに扔いて，溶媒の添加は有効であ ると広く認識されている。

コールタールピッチの接触水素化改質に扔いて, 反応溶媒と してトルエン・テトラリン混合溶媒を用いた例1,2) や，高水素 供与能を有するテトラヒドロフルオランテンを溶剤として低圧 気相の水素共存下で石炭の水素移動液化を行った例3),4) が報告 されている。また, 減圧残油 (VR) と水素供与剂としてテト ラヒドロフルオランテンの存在下で熱改質を行うことで, 重質 成分であるアスファルテンのアルキル側鎖を効果的に切断し， 低分子化できるとの報告もある5)

さらに, 常圧残油 ( $\mathrm{AR}$ ) の水素化分解にテトラリンを用い た研究6) が報告されている。そこでは, テトラリン共存下で $\mathrm{AR}$ の水素化分解を行うことで, AR 中の重質成分であるレジ ンやアスファルテンが効果的に分解する一方, コークの生成は 無視できる程度である。この際, 触媒が存在しない場合でも溶 媒添加効果はあるが, NiMo 触媒を用いるとテトラリンから油 への水素移行が促進する。

* To whom correspondence should be addressed.

* E-mail: h_mizutani@ cosmo-oil.co.jp
プロパン脱れき残さの水素化処理において, シクロヘキサン やベンゼンのような軽質炭化水素溶剤を添加した検討も行われ ている7)。ここでは, 溶剤添加により水素化脱硫 (HDS) 反応 が進み, 比較的重質成分の分解が促進されるとしている。また, ナフテン類を相対的に多く含む脱れき油の飽和分には, 水素供 与能により, 熱分解時に芳香族分および極性化合物からのコー ク生成を抑制する作用があるとしている。

一方, 反応溶媒に超臨界水を用いた研究として, ARの水素 化や水素化分解に一酸化炭素と水の混合物 (CO-Steam) を還 元剤として用いた例が報告されている8)。ここでは, Co-Mo 系 の触媒を用いて $375^{\circ} \mathrm{C}$ 以上の温度域で反応を行うと, 水性ガス シフト反応と HDS 反応が並発する。超臨界水十水素 $\left(\mathrm{SCW}-\mathrm{H}_{2}\right)$ 系と超臨界水十一酸化炭素 (SCW-CO) 系を比較 するため, Ni-Mo 系の触媒を用いて $400^{\circ} \mathrm{C}, 30 \mathrm{MPa}$ の条件で, ジベンゾチオフェンとヘキシルベンゼンをモデル化合物として 用いた検討を行った報告もある9”。どちらの系においても HDS が進行しているが， SCW-CO系の方が SCW-H 系よりも高い 水素化活性が得られるとしている。これは, 水性ガスシフト反 応により水素が生成して HDS が進行しただけでなく, 水性ガ スシフト反応により生成した水素の活性が通常の水素より高い ことを示している。これらの研究では, 水は超臨界状態にある とされているが, 水の効果発現に超臨界状態が必須とは思われ 
Table 1 Properties of Feedstock

\begin{tabular}{lrc}
\hline & & AL-AR \\
\hline Density & {$\left[\mathrm{g} / \mathrm{cm}^{3}\right]$} & 0.9713 \\
Sulfur & {$[\mathrm{mass} \%]$} & 3.42 \\
$\mathrm{CCR}$ & {$[$ mass\%] } & 10.4 \\
Metal $(\mathrm{Ni}+\mathrm{V})$ & {$[$ mass ppm] } & 50 \\
Asphaltene & {$[$ mass\%] } & 2.9 \\
\hline
\end{tabular}

CCR: Conradson carbon residue.

ない。

筆者らは, AR の水素化処理を行う直接脱硫装置（直脱）に おいて, 水を添加することで HDS および水素化脱金属 (HDM) 活性は向上し，触媒劣化が抑制されることを見出し，水の添加 効果および作用機構に関する検討を行ってきた10)。この条件で は，水は超臨界条件には達していないが，水を添加することで 触媒上のコーク生成が抑制された。特に，コークや金属がある 程度たい積した反応中期の触媒上では, 生成ガス中の $\mathrm{C}_{1}, \mathrm{C}_{2}$ パラフィンの生成が抑制された。これは，接触的な水素化分解 が促進され，熱分解反応が抑制されたことを示唆している。ま た, 水の添加によりアスファルテンは減少し, 水素化が進行し た。この際，低分子量のアスファルテンがマルテン分へ転化 し, 高分子量のアスファルテンには変化が見られなかった。減 少したアスファルテン分はレジン分や芳香族分に転化するが, 飽和分への転化は少ない。こうした水の添加効果は，水を水素 供与剂とする水素化分解, 水性ガスシフト反応による水素化分 解, 触媒上の吸着物の溶解による触媒の活性向上および劣化抑 制が考えられる。筆者らは, 水の添加効果は, 触媒に強吸着し たアスファルテンを触媒上から脱離（ストリッピング）して， コーク生成を抑制する効果によると考察した。水の添加を停止 すると, ストリッピング効果がなくなるため, 水添加効果は消 失する。このように水の添加のコーク生成に対する効果は可逆 的に作用する。一方，筆者らの条件では，水添加に扔いて反応 中に $\mathrm{CO}$ や $\mathrm{CO}_{2}$ は検出されず, $\mathrm{CO}-\mathrm{H}_{2} \mathrm{O}$ による水性ガスシフト 反応による水素化やコークのガス化は除外できた。

本研究では, 残油の水素化処理に対する溶媒効果に打ける水 の特異性を検証する。比較に用いた溶媒としては，水素供与性 物質であるテトラリンと, 水素供与性はないが良溶媒である 1-メチルナフタレンを選択した。また，水の極性物質としての 作用を検証するため, 強極性物質としてフェノールを選択し た。さらに，上記の有機溶媒と比較して，高沸点成分であり， 芳香族化合物の含有量の大きい分解軽油も選択した。選定した 溶媒を添加して, 脱硫活性の評価を行うとともに, 使用後触媒 上のコークたい積量を調べた。また, 分解活性や生成油の組成 についても調べ, 添加する溶媒の作用機構を考察した。

\section{2. 実験 方 法}

本研究では, Ni-Mo 系の触媒を用いて回分式触媒活性評価 を行った。原料油には, 中東系のアラビアンライト常圧残油 (AL-AR) を用いた。原料油の性状を Table 1 に示す。

評価方法としては, 回分式高圧小型反応装置（オートクレー ブ）を用いて, 触媒量 $20 \mathrm{ml}$, 原料油 $50 \mathrm{~g}$, 溶媒の添加量は 1
Table 2 Reaction Conditions

\begin{tabular}{lrc}
\hline Reaction temperature & {$\left[{ }^{\circ} \mathrm{C}\right]$} & 400 \\
$\mathrm{H}_{2}$ partial pressure & {$[\mathrm{MPa}]$} & 10.3 \\
Reaction time & {$[\mathrm{h}]$} & 3 \\
\hline
\end{tabular}

Table 3 Properties of Solvent

\begin{tabular}{lrcccc}
\hline & & $\mathrm{H}_{2} \mathrm{O}$ & Tetralin & 1-MN & Phenol \\
\hline$M W$ & & 18 & 132.2 & 142.2 & 94.1 \\
Density & {$[\mathrm{g} / \mathrm{m} l]$} & 0.998 & 0.976 & 1.023 & 1.080 \\
$B p$ & {$\left[{ }^{\circ} \mathrm{C}\right]$} & 100 & 207.6 & 244.8 & 181.8 \\
$T_{\mathrm{c}}$ & {$\left[{ }^{\circ} \mathrm{C}\right]$} & 374 & 448 & 499 & 421 \\
$P_{\mathrm{c}}$ & {$[\mathrm{MPa}]$} & 22 & 3.7 & 3.6 & 6.1 \\
\hline
\end{tabular}

$M W$ : Molecular weight, $B p$ : Boiling point, $T_{\mathrm{c}}$ : Critical temperature, $P_{\mathrm{c}}$ : Critical pressure.

Table 4 Properties of LCO

\begin{tabular}{lrc}
\hline Density & {$\left[\mathrm{g} / \mathrm{cm}^{3}\right]$} & 0.9640 \\
Sulfur & {$[\mathrm{mass} \%]$} & 2.80 \\
Nitrogen & {$[\mathrm{mass} \mathrm{ppm}]$} & 46 \\
Composition & {$[\mathrm{vol} \%]$} & \\
$\quad$ Saturates & & 33.0 \\
$\quad$ Olefins & & 3.1 \\
\multicolumn{1}{c}{ Aromatics } & 1-ring & 41.1 \\
& 2-ring & 15.9 \\
& $3^{+}$-ring & 6.9 \\
\hline
\end{tabular}

$\mathrm{m} l$ で行った。触媒形状は, 四葉型のペレット状のものを使用 した。オートクレーブの反応条件を Table 2 に示す。原料油の かくはん方法は, 反応器中央部のシャフトの先端にかくはん用 パドルを有する誘導かくはん式で行った。な拉, 検討に用いた 溶媒としては，テトラリン，1-メチルナフタレン (1-MN), フ エノール, 分解軽油 (LCO) を使用した。検討に用いた溶媒の 物性を Table 3 に, LCO の性状を Table 4 に示す。新触媒は 所定の条件で予備硫化を行った後に反応に使用した。一方, 使 用済み触媒はトルエンを用いてソックスレー抽出により触媒上 の残油分を除去し， $100^{\circ} \mathrm{C}$ で $6 \mathrm{~h}$ 乾燥した後に分析を行った。

触媒上の金属分析は高周波プラズマ発光金属分析計（島津製 作所社製, ICPS-2200）を用い, 硫黄分析は赤外吸収式硫黄分 析計 (LECO 社製, SC-132) を用い, コーク分析は CHN 分析 計（柳本社製，MT-3）を用いて行った。

また，反応生成油の蒸留性状については，ガスクロマトグラ フ (Analytical Controls 社製, AC6890) を用いて行った。ガス クロマトグラフ $(\mathrm{GC})$ の分析は, 高温 GC 蒸留 (SIMDIS) 用 のカラム (Analytical Controls 社製, SIMDIS HT 750: 0.53 mmI. D. $\times 5 \mathrm{ml}$, Film $0.09 \mathrm{~mm}$ ) と検出器として FID (flame ionization detector）を用いて行った。二硫化炭素 $\left(\mathrm{CS}_{2}\right)$ でバックグ ラウンドのデータを採取した後， $\mathrm{C}_{5} \sim \mathrm{C}_{120}$ のノルマルパラフ インをキャリブレーション用の試料として分析した。また，実 試料は $0.2 \mathrm{~g}$ サンプリングし, $10 \mathrm{~g}$ の $\mathrm{CS}_{2}$ で希釈して分析を行 った。 


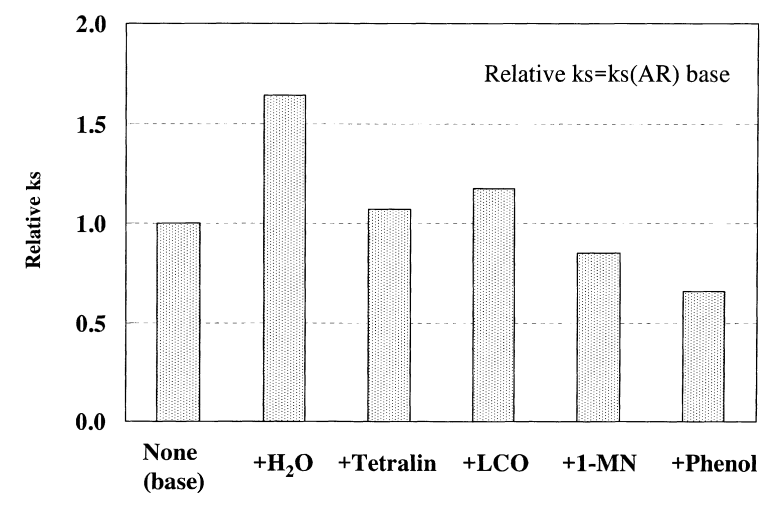

Fig. 1 Comparison of HDS Activity

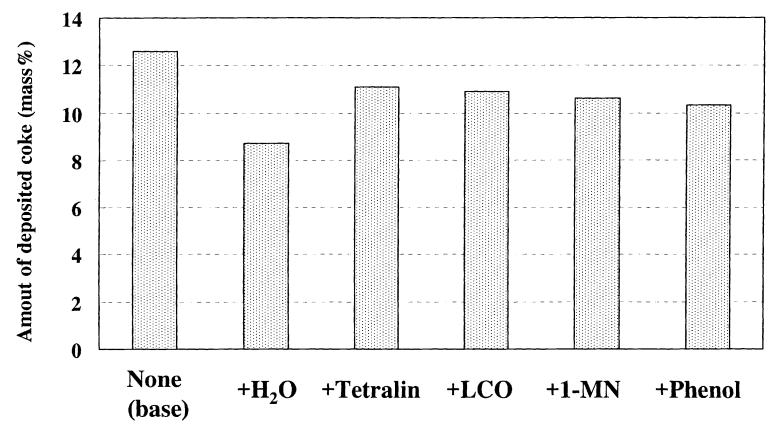

Fig. 2 Comparison of the Amount of Deposited Coke on Catalyst

\section{3. 実 験 結 果}

\section{1. AR の水素化処理における溶媒添加効果}

Table 3 に示す 4 種類の溶媒と Table 4 に示す LCO を同じ 容量 $(1 \mathrm{ml})$ 添加してオートクレーブによる活性評価を行った。 HDS 活性の比較を Fig. 1 に示す。なお, HDS 活性は Eq. (1) に 示す二次の反応速度式で整理し, AR, 無溶媒時の HDS 速度定 数 $(k s)$ を基準とした相対值で示した。

$$
k s=\left(\frac{1}{S_{\mathrm{p}}}-\frac{1}{S_{\mathrm{f}}}\right) \times(\text { LHSV })
$$

ここで, $S_{\mathrm{p}}$ は生成油中の硫黄濃度, $S_{\mathrm{f}}$ は原料油中の硫黄濃度, LHSV は液空間速度（Liquid Hourly Space Velosity）である。な お，本実験はオートクレーブにより行っているため，LHSV は 単位時間あたりに触媒（評価に用いた触媒容積）に接触した原 料油の容積を算出した值を用いた。

Fig. 1 より, HDS 活性の序列は $\mathrm{H}_{2} \mathrm{O}>\mathrm{LCO}>$ Tetralin $>\mathrm{AR}$ (base) > 1-MN > Phenol の順となり, 水の添加効果が顕著に優 れている。1-MN および Phenol に関しては，基準とする ARの HDS 活性よりも低下しており, 反応阻害要因になっている。 一方，LCO の添加は HDS 活性の向上に有効であった。

オートクレーブによる活性評価終了後，反応生成油㧍よび使 用済み触媒を取り出し, 触媒上のコークたい積量を測定した。 コークたい積量の比較を Fig. 2 に示す。Fig. 2 より，コーク のたい積量は AR (base) > Tetralin > LCO > 1-MN > Phenol >

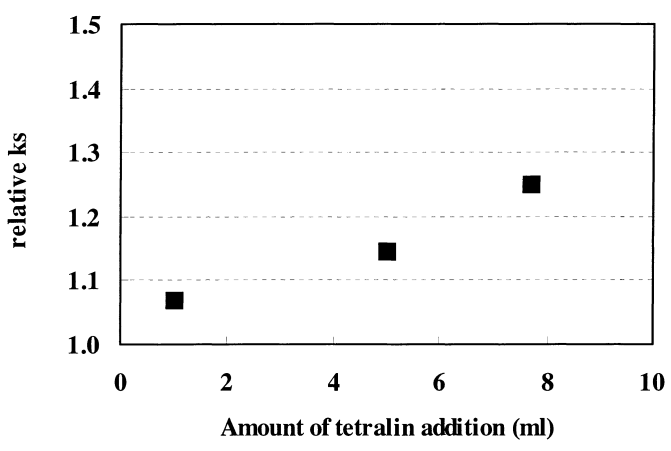

Fig. 3 Relationship between HDS Activity and the Amount of Tetralin Addition

$\mathrm{H}_{2} \mathrm{O}$ の順に減少し, 溶媒の添加によりいずれもコークたい積 量が低減していた。この結果から, 添加した溶媒が, 触媒上へ 吸着するアスファルテンの重質成分を脱離し, コークの生成を 抑制したことが溶媒効果の一因であろうと考えられる。水を除 いて, 全ての溶媒ではコークたい積量は減少するが, HDS 活 性は全て向上している訳ではない。コーク抑制効果の大きい 1-MN, Phenol では HDS が減少しているのに対して, Tetralin, LCO は HDS を促進する。これら添加溶媒も触媒上に一定時間 滞留し, その間アスファルテンの触媒への接触を妨害する競争 効果も考えられる。さらに, 吸着アスファルテンと反応して, 分解や脱硫を妨害する溶媒もあると考允られる。

Table 4 に示すように, LCO の約 7 割近くは芳香族分で構成 されている。LCOは, 他の添加溶媒と比較して高沸点物質で あることから，AR 中のアスファルテン等の重質成分に対する 溶解力が高く, 活性点からのストリッピング効果によると考え られる。Tetralin と 1-MNの HDS 活性に対する差は, Tetralin の持っている水素供与性によると推察される。最後に, Phenol は Table 3 に示すように, 添加溶媒の中で最も低沸点物質であ る。また, 本反応条件では Phenol は気体で存在することがプ ロセスシミュレーターで予測されることから, 最も AR 中のア スファルテン等の重質成分に対する溶解力が小さいであろう。 また，極性物質であることから触媒上の活性点に長時間滞留 し, 反応阻害物質として作用したと推察される。

\section{2. 水の特異性}

オートクレーブの評価において, 溶媒の添加量を容積一定 $(1 \mathrm{ml})$ で比較した結果, $\mathrm{H}_{2} \mathrm{O}$ の添加は $\mathrm{HDS}$ 活性の向上および コークたい積量の抑制に関して顕著な差が見られた。Table 3 に示すように, $\mathrm{H}_{2} \mathrm{O}$ は他の添加溶媒と比較して非常に分子量 が小さいため, 各溶媒の添加量を容積一定とした場合には, $\mathrm{H}_{2} \mathrm{O}$ のモル数が非常に多い。そこで，モル数の影響を検討す るため, 溶媒の中で HDS 活性が最も向上した Tetralinについ て, 添加量を変えて検討を行った。Tetralin の添加量と HDS 活 性との関係を Fig. 3 に示す。Fig. 3 より，Tetralinの添加量を 増やすと, HDS 活性は向上する。そこで, $\mathrm{H}_{2} \mathrm{O}$ と Tetralin の添 加効果について, 容量一定とした場合とモル数一定とした場合 の HDS 活性の比較を Fig. 4 に示す。Fig. 4 より, モル数一定 とした場合, Tetralin の HDS 活性は向上するが, $\mathrm{H}_{2} \mathrm{O}$ には及ば ない。したがって, 添加量を容積一定として添加効果を比較し 
た場合，添加モル数が HDS 活性に影響するものの, $\mathrm{H}_{2} \mathrm{O}$ の特 異的な性質が添加効果を特に大きくしていると考えられる。

次に,コークたい積量の比較を行った。 $\mathrm{H}_{2} \mathrm{O}$ と Tetralinの添 加効果について, 容積一定とした場合とモル数一定とした場合 のコークたい積量の比較を Fig. 5 に示す。Fig. 5 より，添加 溶媒の容積一定条件で比較した場合には，コークのたい積量は Tetralin 添加の方が多いという結果であったが，モル数一定条 件で比較した場合，コークたい積量は同じになる。したがっ て, コークたい積量に対しては, 添加した溶媒が触媒上へ吸着

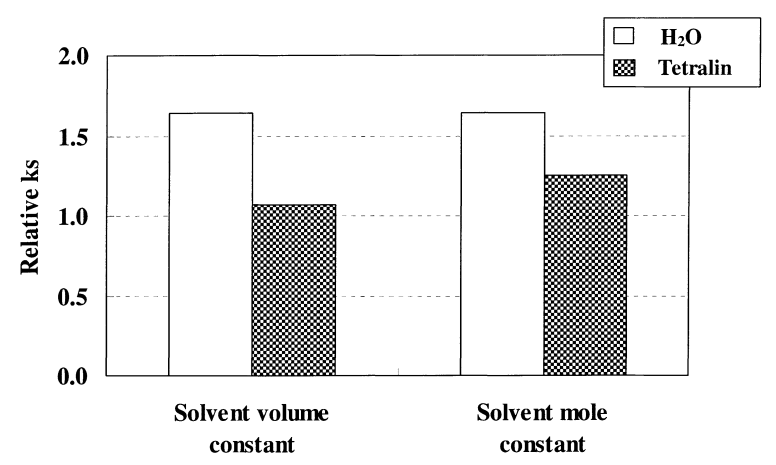

Fig. 4 Comparison of HDS Activity

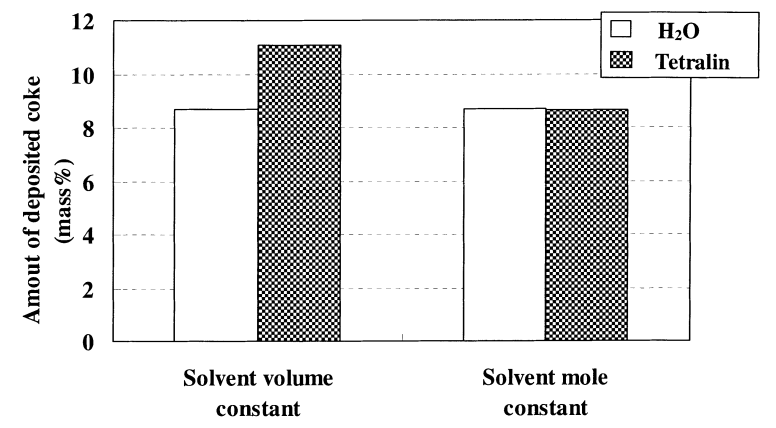

Fig. 5 Amount of Deposited Coke on Catalyst
するアスファルテンやコーク前駆体を脱離する溶媒効果が考え られるが, 添加量をモル数一定で比較した場合, 容積一定の場 合よりも Tetralinの分子数が増加するため, 大きな溶媒効果が 得られたと考えられる。

\section{3. 溶媒添加による生成油の組成比較}

上記検討で得られた生成油について，GCにより SIMDIS を 行った。基準となる $\mathrm{AR}$ の反応生成油抒よび各溶媒の添加量を 容積一定とした生成油の蒸留性状を Table 5 に示す。ここでは $166^{\circ} \mathrm{C}$ までを Naphtha 留分, $166 \sim 229^{\circ} \mathrm{C}$ を Kerosene 留分, 229 $343^{\circ} \mathrm{C}$ を軽質油 ( $\mathrm{LGO}$ ) 留分, $343^{\circ} \mathrm{C}$ 以上を $\mathrm{AR}$ 留分とした。 Table 5 より, 基準である $\mathrm{AR}$ の反応生成油と $\mathrm{H}_{2} \mathrm{O}$ を添加した 反応生成油の分解率 (100- AR の得率) は同等であり, 他の 溶媒を添加した場合は約 $1 \%$ 程度分解率が向上した。 GC 分析 で得られたクロマトグラムから, 低沸点側に溶媒のピークが検 出された。そこで, 溶媒の残存量を調べるため, Tetralin, 1MN および Phenol について標準試料を作成し, SIMDIS と同じ 条件で GC 分析を行った。また, 標準試料の分析で得られたク ロマトグラムの保持時間から, 実試料における溶媒の残存ピー クを同定し, 得られたピーク面積から絶対検量線法により溶媒 の残存量を求めた。

AR の反応生成油のクロマトグラムを Fig. 6 に示す。同様 に, Tetralin 添加した反応生成油のクロマトグラムを Fig. 7 に，1-MNを添加した反応生成油のクロマトグラムを Fig. 8 に, Phenol を添加した反応生成油のクロマトグラムを Fig. 9 に示す。なお，クロマトグラムは低沸点側のピークを拡大して

Table 5 Fraction Yield [mass \%]

\begin{tabular}{lcccc}
\hline & Naphtha & Kerosene & LGO & AR \\
\hline None (base) & 0.1 & 2.0 & 15.8 & 82.1 \\
Tetralin & 0.1 & 3.3 & 15.5 & 81.1 \\
LCO & 0.2 & 3.2 & 16.5 & 80.1 \\
$\mathrm{H}_{2} \mathrm{O}$ & 0.1 & 1.9 & 15.4 & 82.6 \\
1-MN & 0.3 & 4.1 & 14.4 & 81.2 \\
Phenol & 0.5 & 3.1 & 15.3 & 81.1 \\
\hline
\end{tabular}

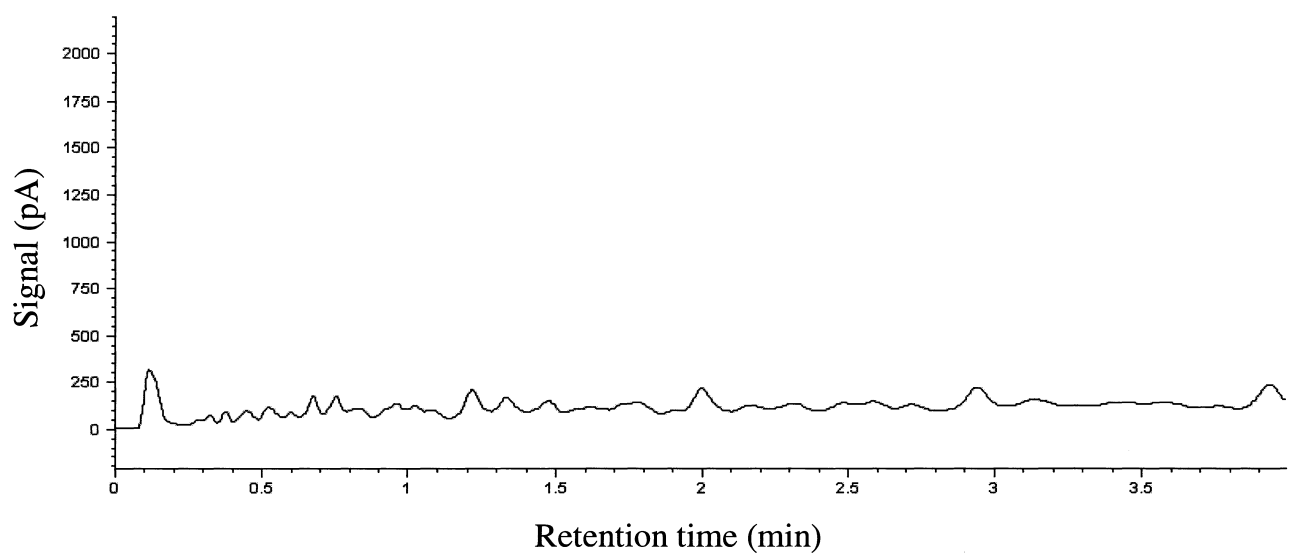

Fig. 6 Chromatogram of Product Oil from AR Hydrotreating 


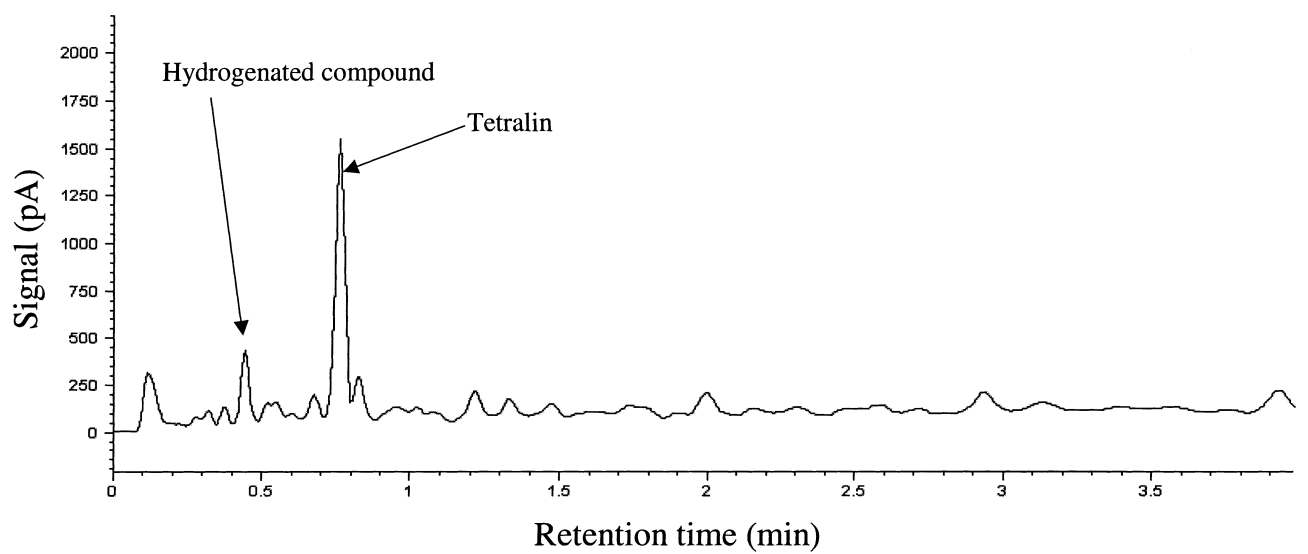

Fig. 7 Chromatogram of Product Oil from AR Hydrotreating with Tetralin Addition

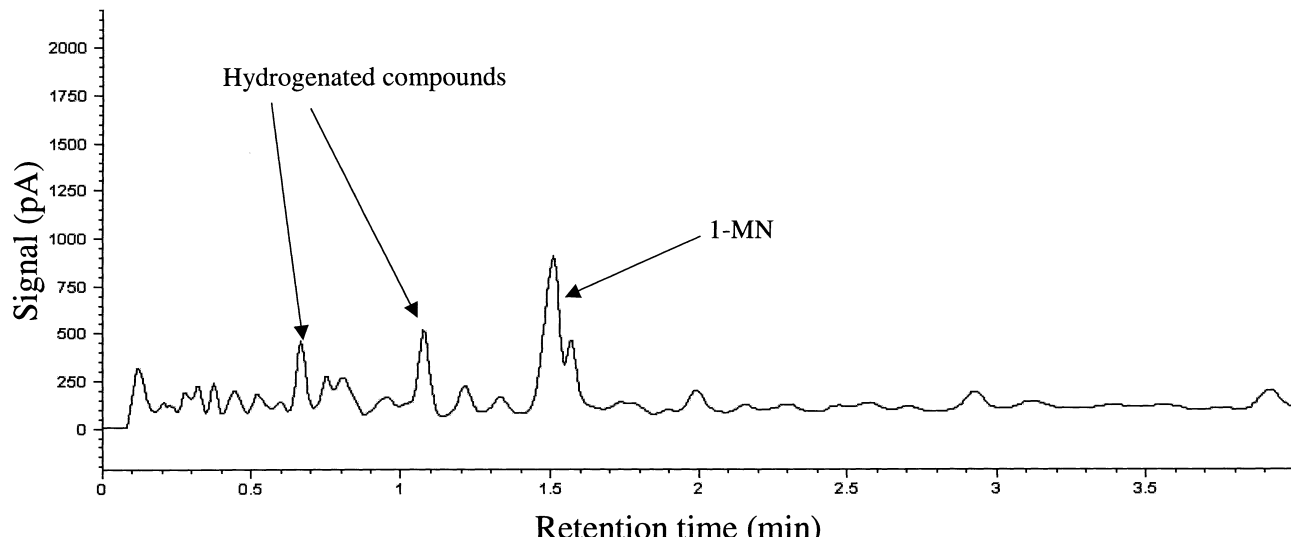

Fig. 8 Chromatogram of Product Oil from AR Hydrotreating with 1-MN Addition

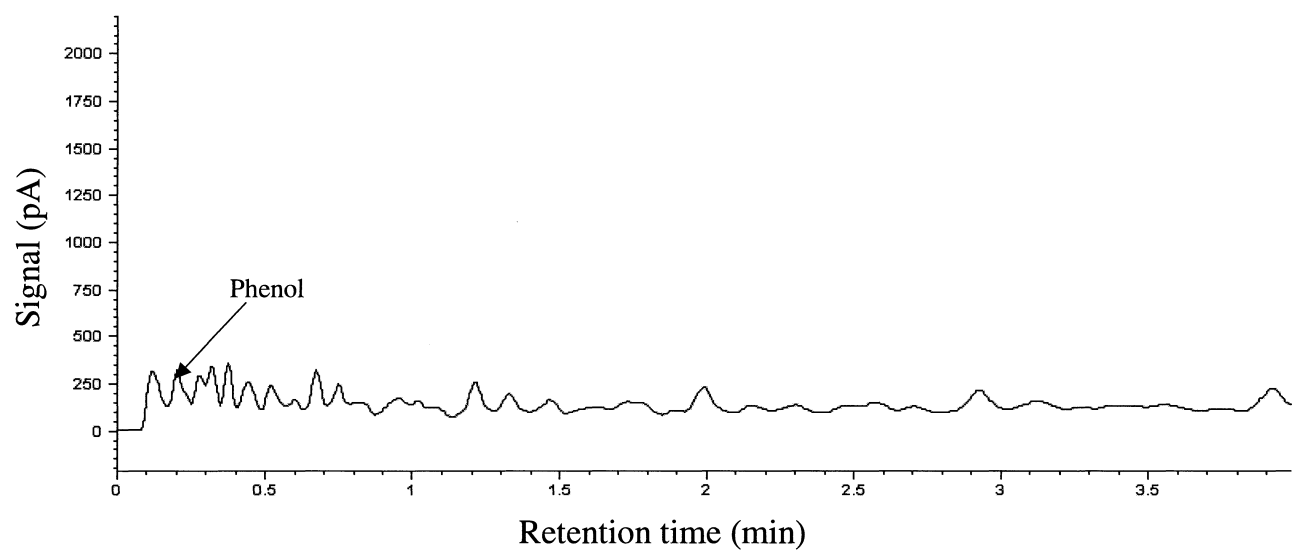

Fig. 9 Chromatogram of Product Oil from AR Hydrotreating with Phenol Addition

示した。Figs. 7, 8 および9に示すように, 添加した溶媒が生 成油中に残存しているために，見かけ上分解率が向上する。し たがって, この点を考慮すると, 溶媒添加は分解率の向上には ほとんど寄与しない。
また，オートクレーブによる反応で添加した溶媒の転化率を Eq. (2)に示す式で算出した。

$$
\text { Solvent conversion }=\frac{(\text { Sol. } f-\text { Sol. } p)}{\text { Sol.f } f} \times 100
$$




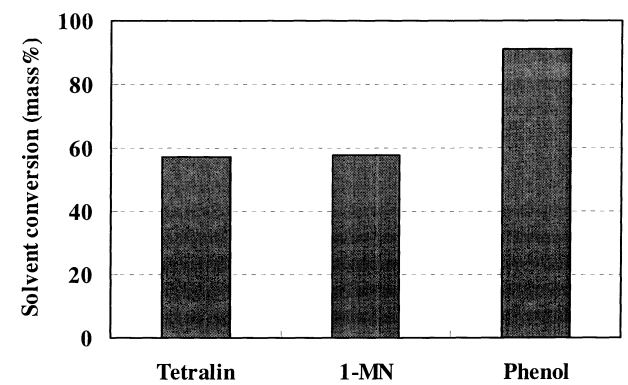

Fig. 10 Solvent Conversion during AR Hydrotreating

ここで, Solvent conversion は溶媒自身の転化率，Sol.f は原料 油中の溶媒濃度, Sol.p は生成油中の溶媒濃度である。Solvent conversion を Fig. 10 に示す。なお，検出器として FID を用い ているため， $\mathrm{H}_{2} \mathrm{O}$ は検出できないことと，LCOに関しては単 一成分ではないため正確に LCO 留分の転化率を算出すること は難しいことから，この二つのケースは除外した。

Fig. 10 より, Tetralin と 1-MN は約 6 割が他の成分に転化し たのに対して, Phenol は約 9 割が転化した。Table 5 に示すよ うに, Phenol の沸点が $181.8^{\circ} \mathrm{C}$ であることと, Phenol を添加し た生成油の蒸留性状は $166^{\circ} \mathrm{C}$ までの Naphtha 留分が増加してい ることが分かった。Fig. 9 に示すように，1 環芳香族に由来す るピークが多く検出されたこと等から, Phenol が反応して Toluene, Benzene，あるいは Cyclohexane 等に変化したと考え られる。

Phenol は残油との競争に扔いて, 触媒上の活性点に対して 優先して吸着し, 反応中 Phenol が活性点を占有するため, 残 油の反応を阻害する。Phenol の活性点への優先的吸着は, ア スファルテン等のコーク前駆体の吸着を減少し, さらに溶媒と して触媒上より前駆体を溶解するため, 触媒上のコークたい積 量は低減できると考えられる。

一方， Fig. 7 に示すように，Tetralin を添加した反応生成油 のクロマトグラムから, Tetralin の残存ピークに加えて低沸点 側に Tetralinの水素化物に由来するピークが検出された。これ は, Tetralin が水素化されて Decalin に変化したと考えられる。 さらに, Fig. 8 に示すように，1-MN を添加した反応生成油の クロマトグラムから，1-MN の残存ピークに加えて低沸点側に 1-MN の水素化物に由来するピークが検出された。これは，1$\mathrm{MN}$ の芳香環の一部が水素化された化合物に変化したと推察さ れる。Tetralin 抢よび 1-MN 自身も水素化されることから， Tetralin も1-MNもどちらも触媒上の活性点に吸着して, 脱硫 反応を阻害する。溶媒自身の転化率は溶媒自身の水素化の程度 （反応率）を表現していると考えると，水素化の程度が高い溶 媒は活性点に長く滞留していると考えられるので, 転化率から 活性点に扮ける滞留時間を類推できる。したがって, Tetralin および 1-MN の転化率はいずれも Phenol の半分程度であるこ とから, 活性点での滞留時間は短いと推察できる。Tetralin と 1-MNの溶媒自身の転化率が同等であるにもかかわらず，1MN の場合, HDS 活性が低下する理由としては, 効果は小さ いかも知れないが, Tetralinの水素供与能による強吸着物の脱 離促進によると推察される。

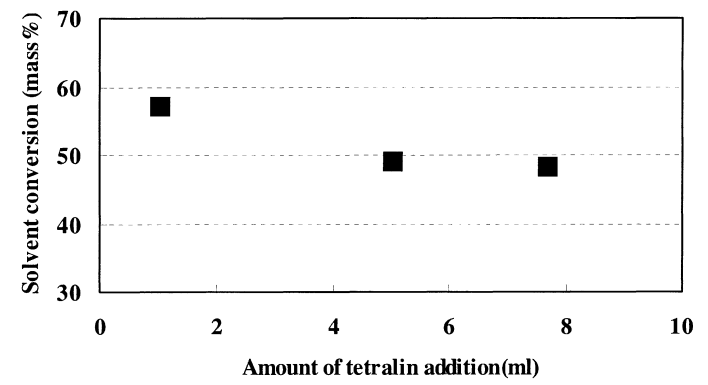

Fig. 11 Relationship between Solvent Conversion and the Amount of Tetralin Addition

さらに, Tetralinの添加量と溶媒自身の転化率との関係を Fig. 11 に示す。Fig. 11 より, Tetralinの添加量を増加させる と溶媒の転化率が低下するが, 添加量が $5 \mathrm{ml}$ 以上では溶媒の 転化率はほぼ一定であった。つまり, 活性点の占有はほぼ飽和 していると考えられる。したがって, 同じ添加溶媒において も, 添加量を増加すれば活性点の占有は変わらず, 溶媒効果に よる触媒上へ吸着するアスファルテンやコーク前駆体に対する ストリッピングが増大し, HDS やコーク生成の抑制に効くと 考えられる。

\section{4. 考察}

残油の直接脱硫において, 水等の添加により脱硫反応が促進 されるが, その効果は添加物の特性を反映する。本研究では, $\mathrm{H}_{2} \mathrm{O}>\mathrm{LCO}>$ Tetralin $>$ AR (base) $>1-\mathrm{MN}>$ Phenol の序列で $\mathrm{HDS}$ を促進することを見出した。 $\mathrm{H}_{2} \mathrm{O}$ 添加効果は極めて顕著 であった。本研究では, 添加物を等容量添加しているため, 低 分子の $\mathrm{H}_{2} \mathrm{O}$ は他の添加物と比較して添加したモル数は特に大 きいが, 等モル数で比較しても大きな効果は認められる。

脱硫反応に扔ける, 添加物の触媒活性点周辺での挙動は以下 のように推察できる。

（1）触媒上に強吸着する高沸点, 高極性化合物の溶解平衡によ る脱離促進

（2）触媒上の脱硫生成物の脱離促進

（3）触媒上に吸着して, 水素供与点, 酸性点としての作用

（4）触媒上に吸着した硫黄の脱離 $\left(\mathrm{H}_{2} \mathrm{~S}\right.$ または $\mathrm{SO}_{2}$ として脱 硫)

（5）触媒に吸着して活性点を占有することによる反応阻害

触媒上にたい積するコーク量を求めると, AR (base) > Tetralin $>\mathrm{LCO}>1-\mathrm{MN}>$ Phenol $>\mathrm{H}_{2} \mathrm{O}$ の順であった。これは, 重質成分や極性成分に対する添加物の溶解力によりコーク生成 が抑制された結果と思われる。生成物を詳細に分析して添加物 の反応率を求めたところ, Phenol $(90)>$ Tetralin $(60) \doteqdot 1-M N$ （60）であった。ここで, Tetralinの反応は主に脱水素であるこ とから, 脱硫反応を阻害するとは考えられない。Tetralinの水 素供与能によりコーク生成が抑制されると期待されるが, Tetralin 自身も一部水素化されるため, 効果は小さいのであろ う。一方, 極性の高い Phenol は残油に優先して吸着し, 水素 化あるいは水素化分解反応が顕著に進むため, 活性点を競争し て占有し, 脱硫反応を阻害する可能性は高い。1-MN は水素化 
されることを考えると，脱硫反応の阻害が考えられる。これ は, Langmuir 型の競争吸着機構で説明できる ${ }^{11)}$ 。うまり，脱 硫や水素化反応はそれぞれ独立して進行しているのではなく, 触媒表面上で抢互いの反応を阻害しながら競争して進行する。 本研究の場合, 残油中の硫黄化合物と Phenol, 1-MN とがそれ ぞれ競争して反応が進行する。そのため, Phenol, 1-MN が硫 黄化合物の活性点への吸着を阻害するために, 無溶媒時よりも 脱硫率が低下すると考えられる。

また，脱硫生成物の脱離が促進されれば，フリーな脱硫活性 点の数が増加することから, 活性点のターンオーバーが増加 し，脱硫を促進する。こうした効果から $\mathrm{H}_{2} \mathrm{O}$ のストリッピン グによる脱硫促進掞よび Tetralinの水素供与による脱硫促進が 考えられる。

筆者らは, 既報10)において, $\mathrm{H}_{2} \mathrm{O}$ の添加効果および作用機 構について報告しており, 本研究では $\mathrm{H}_{2} \mathrm{O}$ の添加効果が他の 添加物と比べて特に大きいことが注目される。 $\mathrm{H}_{2} \mathrm{O}$ は, 上記 で考察した（1），(2）の項目について, 脱硫を促進し, コーク 抑制効果が大きいと推察される。このように， $\mathrm{H}_{2} \mathrm{O}$ が高い添 加効果を示すのは, $400^{\circ} \mathrm{C}, 10 \mathrm{MPa}$ の高温高圧の水蒸気が良溶 媒として機能していると考えられる。 $\mathrm{H}_{2} \mathrm{O}$ は他の添加物のよ うに, 活性点に吸着して水素化されることがないため, 脱硫反 応は阻害しない。特に, 硫化物触媒を酸化物に変化させること なく可逆吸着に抽いて高い親和性を示したと推察できる。

以上の考察により, LCO を除く添加物の脱硫促進効果は定 性的に理解できる。

ここで, LCO の添加効果を考察する必要がある。LCO は主 として 2 環，3 環の芳香族化合物で構成されているが，1-MN と比較して脱硫促進効果が大きい。コーク生成について, LCO の重質成分や極性成分に対する溶解力は $1-\mathrm{MN} よ り も$ 低かっ た。一方, 反応中 LCO の芳香族化合物が水素化されるので, 脱硫反応の阻害が大きいと予想されるが, LCO の水素化物の 水素供与性が大きく, コーク生成の抑制, 脱硫生成物の脱離効 果が勝ると推察される。

\section{5. 結言}

本研究では, AR の水素化処理における水の添加効果が LCO, Tetralin, 1-MN, Phenol と比較して, 特異的に大きいことを見
出した。添加物の効果は, 触媒上に强吸着する化合物および脱 硫生成物の脱離促進, 触媒上の水素化供与点, 酸化の誘導, 触 媒上に吸着した硫黄の脱離促進により脱硫反応を促進する一 方, 活性点を占有して反応を阻害すると考察した。溶媒自身の 転化率は, 溶媒自身の水素化の進行度 (反応率) を表現してい ると考えると, 水素化が進行している溶媒は活性点に長く滞留 していると考えられるので, 転化率から活性点における滞留時 間を類推できる。また, 活性点における残油と溶媒の競争吸着 を考えると, 添加物の活性点に扔ける滞留時間が長いと他の反 応基質が活性点に吸着できないため, 反応阻害となる。したが って, 添加物の反応阻害は, 活性評価結果とその転化率から考 察した。このような脱硫反応の促進に加えて, 触媒上のコーク 生成の抑制が触媒劣化を防止する。これらについて, 水がいず れも関与しており, 特異的な効果を示すのであろう。

\section{謝 辞}

本研究は, 経済産業省の補助金をもって(財)石油産業活性化 センターの研究事業として行った。ここで, 感謝の意を表す る。

\section{References}

1) Adschiri, T., Suzuki, T., Arai, K., Fuel, 70, 1483 (1991).

2) Adschiri, T., Nakada, K., Ogasawara, S., Arai, K., Kagaku Kogaku Ronbunshu, 20, 965 (1994).

3) Mochida, I., Yufu, A., Sakanishi, K., Korai, Y., Fuel, 67, 114 (1988).

4) Mochida, I., Sakata, R., Sakanishi, K., Sasaki, M., Nenryo Kyokaishi, 69, (6), 461 (1990).

5) Mochida, I., Korai, Y., Sakanishi, K., Todo, Y., Ohyama, T., Sekiyu Gakkaishi (J. Jpn. Petrol. Inst.), 34, (4), 303 (1991).

6) Lin, G. C., Lo, C. L., Huang, Y. L., Sekiyu Gakkaishi (J. Jpn. Petrol. Inst.), 32, (1), 1 (1989).

7) Miura, M., Nomura, M., Sekiyu Gakkaishi (J. Jpn. Petrol. Inst.), 40, (3), 154 (1997).

8) Takemura, Y., Itoh, H., Ouchi, K., Sekiyu Gakkaishi (J. Jpn. Petrol. Inst.), 24, (6), 357 (1981).

9) Adschiri, T., Shibata, R., Sato, T., Watanabe, M., Arai, K., Ind. Eng. Chem. Res., 37, 2634 (1998).

10) Mizutani, H., Kiriyama, K., Kondo, K., Idei, K., Mochida, I., J. Jpn. Petrol. Inst., 47, (2), 107 (2004).

11) Girgis, M. J., Gates, B. C., Ind. Eng. Chem. Res., 30, 2021 (1991). 
要旨

\title{
残油水素化処理における溶媒添加による触媒の活性向上および劣化抑制
}

\author{
水谷 洋 ${ }^{\dagger 1), ~}{ }^{\dagger 2}$, 桐山 和幸 ${ }^{\dagger 1)}$, 出井 一夫 ${ }^{\dagger 1)}$, 持田 $\quad$ 勲 $^{\dagger 2), ~}{ }^{\dagger 3}$ \\ †1) コスモ石油(株)中央研究所，340-0193 埼玉県幸手市権現堂 1134-2 \\ †2）九州大学大学院総合理工学府，816-8580 福岡県春日市春日公園 6-1 \\ †3) 九州大学先導物質化学研究所, 816-8580 福岡県春日市春日公園 6-1
}

本研究では, 触媒存在下で残油の水素化処理条件において溶 媒の添加効果に関して検討し, 残油の水素化処理における水の 特異性を調べた。

溶媒を等容量添加してオートクレーブによる活性評価を行っ た結果，水素化脱硫（HDS）活性の序列は $\mathrm{H}_{2} \mathrm{O}>\mathrm{LCO}>$ Tetralin > None (base) $>1-\mathrm{MN}>$ Phenol であった。一方，触媒 上へのコークたい積量は，溶媒を添加した場合，いずれも低減 した。

Tetralin について, $\mathrm{H}_{2} \mathrm{O}$ と等モル数添加した評価も行った。 Tetralin は添加量の増加とともにHDS 活性は向上したが，等モ ル数で比較しても, $\mathrm{H}_{2} \mathrm{O}$ の添加効果は顕著であり, 特異的に HDS 活性を向上させている。
アスファルテン等の重質成分の脱離促進は，コーク生成を抑 制する一方, 添加溶媒は残油と競争して触媒上の活性点を占有 する。添加溶媒の活性点における滞留時間が長いと, 溶媒自身 は水素化される一方，他の反応基質が活性点に吸着できないた め, 反応阻害となる。したがって, 添加溶媒の反応阻害は活性 評価結果とその転化率から考察した。

$\mathrm{H}_{2} \mathrm{O}$ は, 他の添加溶媒と比べて触媒に強吸着したアスファ ルテンおよび脱硫生成物の触媒上からの脱離促進効果が大き い。また, 他の添加溶媒より触媒上の活性点における滞留時間 は短く, 反応阻害は小さいため, 特異的な添加効果を示すであ ろうと考えられる。 